\title{
Fine Root Dynamics and Forest Production Across a Calcium Gradient in Northern Hardwood and Conifer Ecosystems
}

\author{
Byung Bae Park, ${ }^{1,2}$ Ruth D. Yanai, ${ }^{1, *}$ Timothy J. Fahey, ${ }^{3}$ Scott W. Bailey, ${ }^{4}$ \\ Thomas G. Siccama, ${ }^{5}$ James B. Shanley, ${ }^{6}$ and Natalie L. Cleavitt ${ }^{3}$
}

\begin{abstract}
${ }^{1}$ Forest and Natural Resources Management, SUNY College of Environmental Science and Forestry, 210 Marshall Hall, 1 Forestry Drive, Syracuse, New York 13210, USA; ${ }^{2}$ Division of Forest Ecology, Korea Forest Research Institute, Seoul 130-172, South Korea; ${ }^{3}$ Department of Natural Resources, Cornell University, Ithaca, New York 14853, USA; ${ }^{4}$ USDA Forest Service, Northern Research Station, Campton, New Hampshire 03223, USA $;{ }^{5}$ Yale School of Forestry and Environmental Studies, New Haven, Connecticut 06511, USA; ${ }^{6}$ Water Resources Discipline, US Geological Survey, Montpelier, Vermont 05601, USA
\end{abstract}

\begin{abstract}
Losses of soil base cations due to acid rain have been implicated in declines of red spruce and sugar maple in the northeastern USA. We studied fine root and aboveground biomass and production in five northern hardwood and three conifer stands differing in soil Ca status at Sleepers River, VT; Hubbard Brook, NH; and Cone Pond, NH. Neither aboveground biomass and production nor belowground biomass were related to soil $\mathrm{Ca}$ or $\mathrm{Ca}: \mathrm{Al}$ ratios across this gradient. Hardwood stands had $37 \%$ higher aboveground biomass $(P=0.03)$ and $44 \%$ higher leaf litter production $(P<0.01)$ than the conifer stands, on average. Fine root biomass (<2 $\mathrm{mm}$ in diameter) in the upper $35 \mathrm{~cm}$ of the soil, including the forest floor, was very similar in hardwoods and conifers (5.92 and $5.93 \mathrm{Mg} \mathrm{ha}^{-1}$ ). The turnover coefficient (TC) of fine roots smaller than $1 \mathrm{~mm}$ ranged from 0.62 to $1.86 \mathrm{y}^{-1}$ and in-
\end{abstract}

creased significantly with soil exchangeable Ca $(P=0.03)$. As a result, calculated fine root production was clearly higher in sites with higher soil Ca $(P=0.02)$. Fine root production (biomass times turnover) ranged from 1.2 to $3.7 \mathrm{Mg} \mathrm{ha}^{-1} \mathrm{y}^{-1}$ for hardwood stands and from 0.9 to $2.3 \mathrm{Mg} \mathrm{ha}^{-1} \mathrm{y}^{-1}$ for conifer stands. The relationship we observed between soil $\mathrm{Ca}$ availability and root production suggests that cation depletion might lead to reduced carbon allocation to roots in these ecosystems.

Key words: aboveground biomass; aboveground production; acid rain; Cone Pond; fine root biomass; fine root turnover; fine root production; Hubbard Brook; Sleepers River.

\section{INTRODUCTION}

Acid deposition and forest harvest cause losses of calcium and other base cations from forest ecosys-

Received 5 April 2007; accepted 10 December 2007; published online 27 February 2008.

*Corresponding author; e-mail: rdyanai@syr.edu tems, threatening tree health and forest production (Federer and others 1989; Likens and others 1996). Sugar maple decline has been observed in soils with low Ca (Bailey and others 2004), and has been experimentally reversed by liming (Long and others 1997). Spruce decline, likewise, has been attributed to Ca depletion at high elevation by acid 
deposition (DeHayes and others 1999). Sugar maple and red spruce, therefore, if not the other species associated with them in the northern hardwood forests and spruce-fir forests of the northeastern United States, might be expected to be sensitive to the Ca status of the soils in which they grow, even in areas not currently experiencing declines.

Aboveground responses to the direct effects of acid rain have been well studied (Darrall 1989; McLaughlin and others 1993; DeHayes and others 1999). Understanding belowground responses to environmental factors has been limited by the difficulty of measuring belowground carbon pools and turnover (Gower and others 1996; Vogt and others 1996) as well as by the slow response time of soils and roots. In greenhouse studies, the risk of aluminum stress and nutrient imbalance causing growth and health effects on seedlings is indicated by the Ca:Al ratio of soil solution (Cronan and Grigal 1995). A possible mechanism for red spruce decline is the reduction of $\mathrm{Ca}$ uptake caused by competition with $\mathrm{Al}$ for binding sites in the cortical apoplast of fine roots (Shortle and Smith 1988).

Nutrient availability may strongly influence root dynamics in forest ecosystems, especially when these nutrients are limiting factors for plant growth (Ingestad and Agren 1995). In northern hardwood forests, belowground carbon allocation has been reported to be higher in sites with high nitrogen availability and aboveground production (Nadelhoffer and others 1985; Burton and others 2000). In contrast, in many western coniferous forests in North America, the amount of carbon allocated to fine root production is higher in sites of low fertility (Grier and others 1981; Vogt and others 1986; Gower and others 1992). In southern pines, however, root production is increased by fertilization (King and others 2002). It is difficult to distinguish effects of site from those of forest type when these factors are not independent.

Hardwoods and conifers may differ systematically in root dynamics, with hardwoods having higher root production and turnover (Black and others 1998, Coleman and others 2000). It is not known, however, whether they differ in their response to $\mathrm{Ca}$ availability or $\mathrm{Ca}$ Al ratios. Such a response could prove predictive of future changes in root biomass and turnover in sites where $\mathrm{Ca}$ depletion is ongoing.

Our overall aim is to improve knowledge of belowground dynamics and their role in the response of forest ecosystems to environmental stress. We selected a suite of forest stands at three study sites representing a nutrient gradient from high to low Ca availability (Hornbeck and others 1997). Gradients in base status across and within sites allow us to assess the role of cation availability in forest biomass and production. Our first objective was to compare fine root biomass and production in hardwood and coniferous forest types with contrasting soil calcium status. By combining this information with observations of aboveground production, we were also able to compare carbon allocation above- and belowground in hardwood and coniferous forest types in relation to this gradient. We expected fine root biomass to be greatest at the low-Ca sites, but carbon allocation to fine root production to be lowest, due to lower root turnover. We also expected the depth distribution of roots to be most shallow at the high-Ca sites, because roots tend to concentrate in parts of the soil in which resources are abundant.

\section{Materials AND Methods}

\section{Site Descriptions}

We conducted our study in three forested catchments in the northeastern US (Figure 1), where long-term biogeochemical research provided background information to our field studies.

At the Sleepers River Research Watershed (SR) in the upper Connecticut River basin in northeastern Vermont, we studied four forest stands in watershed 9 (W9). The W9 catchment is underlain by the Waits River formation, a quartz-mica phyllite with beds of calcareous granulite (Shanley and others 1995). A silty, often calcareous glacial till (1$4 \mathrm{~m}$ thick) overlies the bedrock, and striking contrasts in soil base status have been observed across W9. Soils are mainly Spodosols at elevations above $610 \mathrm{~m}$ and Inceptisols at lower elevations.

Sleepers River was clearcut in 1929 and naturally regenerated (Thorne and others 1988). Forest cover is mixed northern hardwoods dominated by sugar maple (Acer saccharum Marsh.), yellow birch (Betula alleghaniensis Britt), and white ash (Fraxinus americana Ehrh.). There are a few conifer-dominated stands with balsam fir (Abies balsamea L.) and red spruce (Picea rubens Sarg.) near the W9 weir and in the upper elevations of the watershed. Three northern hardwood stands encompassing a range in soil base status were chosen for study, together with one conifer-dominated stand.

Hubbard Brook Experimental Forest (HB) is located in the White Mountains in central New Hampshire. This study area is underlain by metasedimentary rocks of the Rangeley Formation, and soils are classified as Haplorthods formed from 

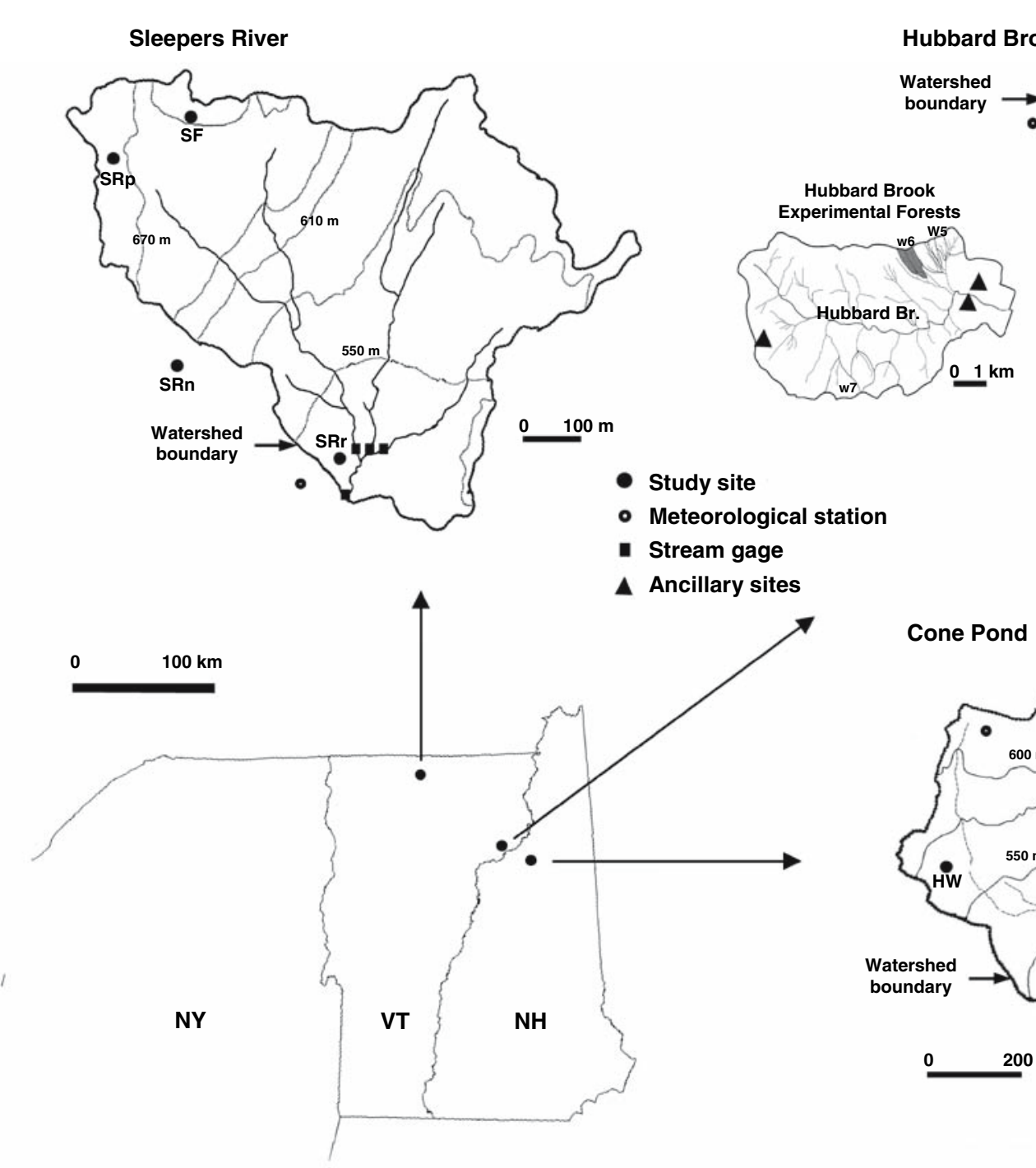

- Meteorological station

- Stream gage

Ancillary sites

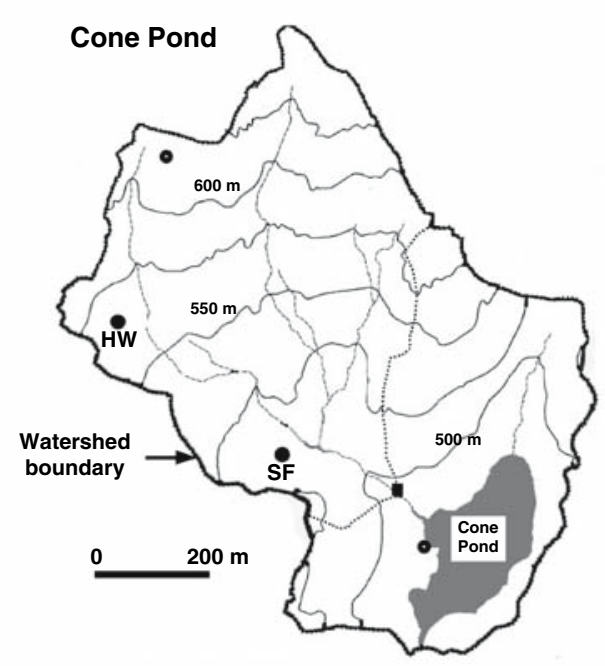

Figure 1. Maps of the three study sites showing the locations of the sampled stands. Abbreviations: CP, Cone Pond; HB, Hubbard Brook; HW, Hardwoods; SF, Spruce-fir; SR, Sleepers River; SRn, new rich-Ca site at SR; SRp, low-Ca site at SR; $\mathrm{SRr}$, rich-Ca site at SR.

a mixture of schist, gneiss, and granitic till. The HB forest was harvested around 1910 and regenerated naturally (Bormann and Likens 1994). Sugar maple, yellow birch, and American beech (Fagus grandifolia Ehrh.) dominate below 710 m elevation. The major species at higher elevations are white birch (B. papyrifera Marsh.), red spruce, and balsam fir. We studied a northern hardwood stand and a spruce-fir-birch stand each adjacent to the reference watershed (W6) (Figure 1). In addition, we utilized ancillary root turnover data from three other northern hardwood stands studied by Cleavitt and others (2008), located elsewhere in the Hubbard Brook valley (Figure 1).

Cone Pond (CP) watershed (Figure 1) is also in the White Mountains, $8 \mathrm{~km}$ from Hubbard Brook.
Bedrock and soils are similar to those at Hubbard Brook. The Cone Pond watershed has never been harvested, but was disturbed by blowdown during a hurricane in 1815 , by a severe wildfire around 1820 , and by another substantial blowdown during a 1938 hurricane (Buso and others 1984). At Cone Pond, one northern hardwood and one conifer stand (dominated by red spruce, eastern hemlock [Tsuga canadensis [L.] Carr.] and balsam fir) were chosen for detailed study.

\section{Soil and Site Characterization}

County soil surveys and reconnaissance observations were used to locate one representative soil pit in each stand. Because similar variability was seen 
in the chemistry of a given genetic horizon within a pit as across a stand, a large sample ( $>2 \mathrm{~kg}$ ) was collected from the four faces of the representative soil pit. Samples were homogenized and split prior to analysis with a riffle sampler. Pedons were described using the protocols of the Soil Survey Division Staff (1993).

Soil samples for chemical analysis were collected by genetic horizon, air-dried, and screened to remove particles larger than $2 \mathrm{~mm}$. Samples were analyzed for $\mathrm{pH}$ in $0.01 \mathrm{M} \mathrm{CaCl}_{2}$ (Robarge and Fernandez 1987). Exchangeable cations (Ca, Mg, $\mathrm{Na}$, and $\mathrm{K}$ ) were determined in $1 \mathrm{M} \mathrm{NH}_{4} \mathrm{Cl}$ extracts (Blume and others 1990). Exchangeable Al was determined in $1 \mathrm{M} \mathrm{KCl}$ extracts. Concentrations of all cations in soil extracts were measured on a Varian Vista axial inductively coupled plasma spectrophotometer. Nitrogen and carbon content were measured on pulverized samples on a Thermo Scientific Flash EA 1112 CHN analyzer.

Soils at the three ancillary northern hardwood sites at $\mathrm{HB}$ were collected and analyzed by the same methods as for the main sites.

We recorded other characteristics of the site for use in testing correlations with fine root biomass and turnover. We recorded the slope, aspect, and elevation of each site. All three sites are characterized by soils with a sandy loam texture; soil texture was not included as a variable because it was consistent across sites. Soil drainage class was indicated by depth to redoxymorphic features.

\section{Aboveground Biomass}

We estimated aboveground biomass for all our stands using parabolic-volume based allometric equations originally developed in 1965 at Hubbard Brook by Whittaker and others (1974) and revised by Siccama and others (1994). Detailed evaluation and uncertainty analysis for the application of these equations at the HBEF were reported by Fahey and others (2005). The HB allometric equations do not include all species occurring in the plots; biomass of hemlock was estimated with equations for red spruce, and red maple (Acer rubrum L.) and white ash (Fraxinus Americana L.) with sugar maple equations.

These equations require estimates of individual tree diameter at breast height $(\mathrm{dbh})$ and height. At $\mathrm{HB}$, dbh was obtained from measurements of all trees in ten plots $(25 \times 25 \mathrm{~m})$ in the lower hardwood zone and nine plots in the spruce-fir zone of the reference watershed, W6 (Figure 1), in 1997. Estimates of tree height were obtained from the relationship between tree height and dbh based on several thousand height measurements from per- manent plots distributed across the HBEF (Schwarz and others 2003).

At CP and SR, we measured diameters of all trees larger than $10 \mathrm{~cm}$ dbh in study plots in each stand. At $\mathrm{CP}$, we used previously established plots: two 0.04 ha conifer plots and three 0.04 ha hardwood plots. At SR, we used two 0.05 ha conifer plots, one 0.1 ha plot at SRp and SRr, the "poor" and "rich" hardwood stands, and four 0.0625 ha plots at SRn, the "new" hardwood stand. To evaluate the applicability of the height-dbh relationships from HBEF at these sites, we measured heights for $47 \mathrm{co}-$ dominiant individuals of the major species across these plots. Ten sugar maples and four ash trees measured at $\mathrm{SR}_{\mathrm{r}}$ and $\mathrm{SR}_{\mathrm{n}}$ were significantly taller at a given dbh than sugar maple at $\mathrm{HB}$, and a proportional correction factor was applied to estimate heights of these species at these two sites. No other species at CP or SR had a significantly different diameter-height relationship from trees at $\mathrm{HB}$, and the HB relationships were used.

\section{Aboveground Production}

We calculated aboveground production as the sum of biomass accumulation (calculated as the increase in biomass based on diameter increase over time) and litterfall production.

To estimate tree growth (diameter increase) at the HB stands, we used measurements of ring width on trees cored near W6 in 1992, 1993, and 1994 (Arthur and others 1999). The relationship of ring width to dbh for each major species was applied to the plot-level dbh data described above. This approach was previously shown to give biomass increment estimates nearly identical to measurements of diameter changes on permanent plots at HB (Fahey and others 2005). For CP and SR, we obtained tree cores in 2003 using an increment hammer (Suunto) from all trees $10 \mathrm{~cm}$ or greater $\mathrm{dbh}$ in each plot. Tree cores were air-dried and sliced with a razor blade to expose a clean surface. The most recent five or six rings were measured to obtain the recent average annual growth rate. The measurements were taken two times per tree core to reduce measurement error.

Litterfall was collected at SR, HB, and CP. At SR, six $0.21 \mathrm{~m}^{2}$ litter traps were randomly located in the SRp, SRr, and spruce-fir stand in 2002 and traps were emptied once per year from 2002 to 2004. At SRn, litter was collected only in 2004 and from only two traps because four were disrupted by bears. At HB, ten $0.094 \mathrm{~m}^{2}$ litter traps were monitored from 1992 to 2003 (Fahey and others 2005). For this study, we used litterfall collected from 
2001 to 2003. At CP, three subplots were established in each stand, each of which had 5 litter traps $\left(1.0 \mathrm{~m}^{2}\right)$; litterfall was collected only in 1991 . Long-term, intensive litterfall measurements at $\mathrm{HB}$ indicate that in the absence of major catastrophic forest disturbance, litterfall remains remarkably constant through time (Knapp and Smith 2001).

\section{Fine Root Collection}

Roots were sampled in June 2003 at SR, HB, and $\mathrm{CP}$. The technique used to collect the cores involved hammering PVC pipe $(5 \mathrm{~cm}$ diameter) into the soil. To reduce soil compaction, the cutting edge of the pipe was sharpened. Soil cores were collected at five plots in each stand at SR, HB, and $\mathrm{CP}$. These plots were established for monitoring root production using minirhizotron tubes and were distributed to give coverage of the stand but avoid signs of recent disturbance, such as tip-up mounds caused by falling trees. A soil probe was used to select soil coring locations to avoid large roots and rocks. The average root core depth was $31 \mathrm{~cm}$.

Four root cores at $1 \mathrm{~m}$ distance from each minirhizotron tube were extracted from each plot (that is, 20 cores per stand). The Oi layer was removed before inserting the core. The organic horizon $(\mathrm{Oe}+\mathrm{Oa})$ was separated based on soil color. The mineral soil was divided into $5 \mathrm{~cm}$ increments up to $35 \mathrm{~cm}$ depth. In the conifer stand at SR, the cores were mostly organic; cores in this case were divided into $5-\mathrm{cm}$ depth increments. Soil cores were kept cool during transport to the lab.

\section{Root Sample Processing and Measurements}

Soil cores were refrigerated at $4^{\circ} \mathrm{C}$ for up to 4 weeks before processing. The depth increments were composited across the four cores in a plot, to give $n=5$ samples per stand. Fine roots $(<2 \mathrm{~mm})$ were manually picked from the composited samples, until only tiny roots $(<0.5 \mathrm{~mm}$ diameter and $5 \mathrm{~mm}$ length) remained; these were picked from a subsample representing one-fourth or one-eighth of the whole volume. The sample and the subsample of soil were weighed before picking and the ratio was used to scale the results. After washing with tap water, live fine roots $(<2 \mathrm{~mm}$ diameter) were sorted into three diameter classes delineated at 0.5 and $1.0 \mathrm{~mm}$. Dead roots smaller than $2 \mathrm{~mm}$ were distinguished from live roots by resilience, brittleness, and color of bark and xylem. Dead roots were not subdivided by diameter. Roots of herbaceous plants were not included in the analysis; these roots were readily distinguished from tree roots by their morphology. The sorted roots were oven dried at $65^{\circ} \mathrm{C}$ for 1 week and weighed. The roots were ashed at $470^{\circ} \mathrm{C}$ and root weights are reported an ash-free basis.

\section{Root Turnover and Production}

Fine root $(<1 \mathrm{~mm}$ diameter) dynamics were monitored using the minirhizotron method (Taylor 1987). Larger roots were not studied because turnover rates of perennial roots larger than $1 \mathrm{~mm}$ diameter are little affected by nutrient availability (King and others 2002). In early summer 2002, five clear butyrate tubes $(5 \mathrm{~cm}$ diameter) were installed to a depth of about $0.5 \mathrm{~m}$ at a $45^{\circ}$ angle in each stand, except at SRn, where five tubes were installed in early summer 2003. In the three additional sites at HB used to augment our sample size, tubes were installed in 2001. An index handle and a hole on each tube allowed positioning of the minirhizotron camera (Bartz Technology, Inc., Santa Barbara, CA). Styrofoam insulation was inserted in each tube to minimize temperature differences between the soil and the tube surface. Following a one-year conditioning period (2 years in our ancillary sites) to minimize the effects of installation (Joslin and Wolfe 1999), images were collected at $25-\mathrm{mm}$ intervals along four sides of each tube on five dates during the snow-free season from July 2003 until July 2004 (from July 2004 until July 2005 at SRn). Growing season precipitation was similar for these two sampling intervals, with no significant drought periods.

We estimated the fine root turnover coefficient $\left(\mathrm{TC}, \mathrm{y}^{-1}\right)$ using a simplified root-number approach (Tierney and Fahey 2001, 2007). Under the assumption of steady-state fine root biomass, TC is the inverse of average fine root longevity and can be used in conjunction with fine root biomass $(\mathrm{Mg}$ $\left.\mathrm{ha}^{-1}\right)$ to estimate fine root production $\left(\mathrm{Mg} \mathrm{ha}^{-1} \mathrm{y}^{-1}\right)$. The TC for fine roots in each tube was calculated as the ratio of the number of new roots observed over the year of observation to the average number of roots observed across all dates. Because it is impossible to reliably distinguish live and dead roots in minirhizotron images, the root numbers include some dead roots, and the TC estimate should be regarded as a relative measure for comparative purposes. This approach is analogous to the fine root production method of Hendrick and Pregitzer (1992) except that root number rather than length was used in the calculations (Gill and Jackson 2000). Although more accurate estimates of TC can be 
obtained by long-term observation of root survivorship, these approaches are very time consuming and the large number of tubes in this study (35) precluded such an approach. To estimate fine root production using these estimates of TC, a correction was needed because the TC does not take into account the long-tailed survivorship curve typically observed for fine roots (Tierney and Fahey 2002). Long-term minirhizotron observations from $\mathrm{HB}$ suggest a correction factor of about 0.45 (Tierney and Fahey 2002). Fine root production was calculated by multiplying the average fine root biomass smaller than $1 \mathrm{~mm}\left(\mathrm{Mg} \mathrm{ha}^{-1}\right)$ times the average TC for each site $\left(\mathrm{y}^{-1}\right)$, corrected by 0.45 . Additional long-term minirhizotron observations will be needed to confirm the accuracy of this correction factor.

\section{Data Analysis}

We used repeated-measures ANOVA to test for differences in fine root biomass among sites, with soil depth as the repeated measure. Analysis of variance procedures with Tukey's studentized range tests were used to test the effect of nutrient availability (site) and forest type (conifer or hardwood) on total fine root biomass and fine root turnover.

Regression analysis was used to predict root biomass as a function of soil depth for each root diameter class in each stand. The slope and intercept did not differ significantly among sites within a forest type, so average response curves were compared across forest types and root diameter classes.

Soil chemical characteristics were measured for multiple horizons, and these horizons differed across sites. We used both a single horizon and a weighted horizon approach to relating soil characteristics to vegetation variables. The single most important horizon is the uppermost (O or A horizon). We also generated weighted average chemical characteristics for each site from the multiple horizons we sampled, using root biomass as the weighting factor. Because the depths of the horizons did not coincide with the depths of root sampling, we used the root biomass density predicted by the linear regressions for each site. For the ancillary sites at $\mathrm{HB}$, where root biomass was not measured, we used the root biomass distribution at the main HB hardwood site.

We used correlation to test the relationship between soil chemical characteristics $(\mathrm{Ca}, \mathrm{Mg}, \mathrm{K}, \mathrm{Na}$, $\mathrm{Al}$, and $\mathrm{N}$ concentrations, $\mathrm{CEC}, \mathrm{Ca} / \mathrm{Al}$ and $\mathrm{Mg} / \mathrm{Al}$ ratios) and vegetation measurements (aboveground production, leaf production, litterfall biomass, fine root biomass, fine root turnover, fine root production, aboveground production/fine root production ratio, litterfall biomass/fine root production ratio). The three ancillary sites at HB were included in analyses of fine root turnover; biomass and production were not measured at these sites.

Fine root production was compared to leaf litter production because leaf litter production is measured easily and because leaf litter production is a critical factor in estimating total carbon allocation to fine roots in forest soils (Raich and Nadelhoffer 1989). Regression analysis was used to test the effect of soil variables on fine root production and on the ratio of fine root production to the sum of root and leaf litter production.

\section{RESUltS}

\section{Soil Chemistry}

Our aim was to examine fine root dynamics in a suite of forest stands of similar structure and composition but with different soil base status. Soil chemical properties differed markedly, both across the three sites and among the stands within the sites (Table 1). For example, $\mathrm{pH}$ of the A horizon ranged from $2.9(\mathrm{CP})$ to $6.2\left(\mathrm{SR}_{\mathrm{n}}\right)$. Exchangeable Ca generally declined with depth, and surface soil Ca concentrations exhibited a 26 -fold range among the hardwood stands and a 5-fold range in the conifers. Notably, the highest and lowest Ca soils both occurred at the SR site. Three ancillary hardwood stands at HB for which minirhizotron and soil chemistry data were available (Cleavitt and others, 2008) extended the range of exchangeable $\mathrm{Ca}$ in the surface horizon for the HB site from 3.5 to $24 \mathrm{cmol}_{\mathrm{c}} \mathrm{kg}^{-1}$.

\section{Forest Stand Composition}

The three conifer stands were dominated by red spruce and balsam fir but with differing mixes of other species. In particular, at CP eastern hemlock was an important species whereas at $\mathrm{HB}$ and SR birches were important (Figure 2). Also, total basal area was higher at CP than at HB and SR. Sugar maple and yellow birch were dominant in all the hardwood stands, but again the mix of associated species differed. Most notably, beech was abundant at both $\mathrm{CP}$ and $\mathrm{HB}$, whereas white ash was important in two of the stands at SR (Figure 2). Total basal area was fairly similar across all the stands, being lowest at $\mathrm{SR}_{\mathrm{P}}\left(26 \mathrm{~m}^{2} \mathrm{ha}^{-1}\right)$ and highest at $\mathrm{SR}_{\mathrm{n}}\left(33.5 \mathrm{~m}^{2} \mathrm{ha}^{-1}\right.$; Figure 2), two stands with similar disturbance history but strikingly different soils (Table 1). 


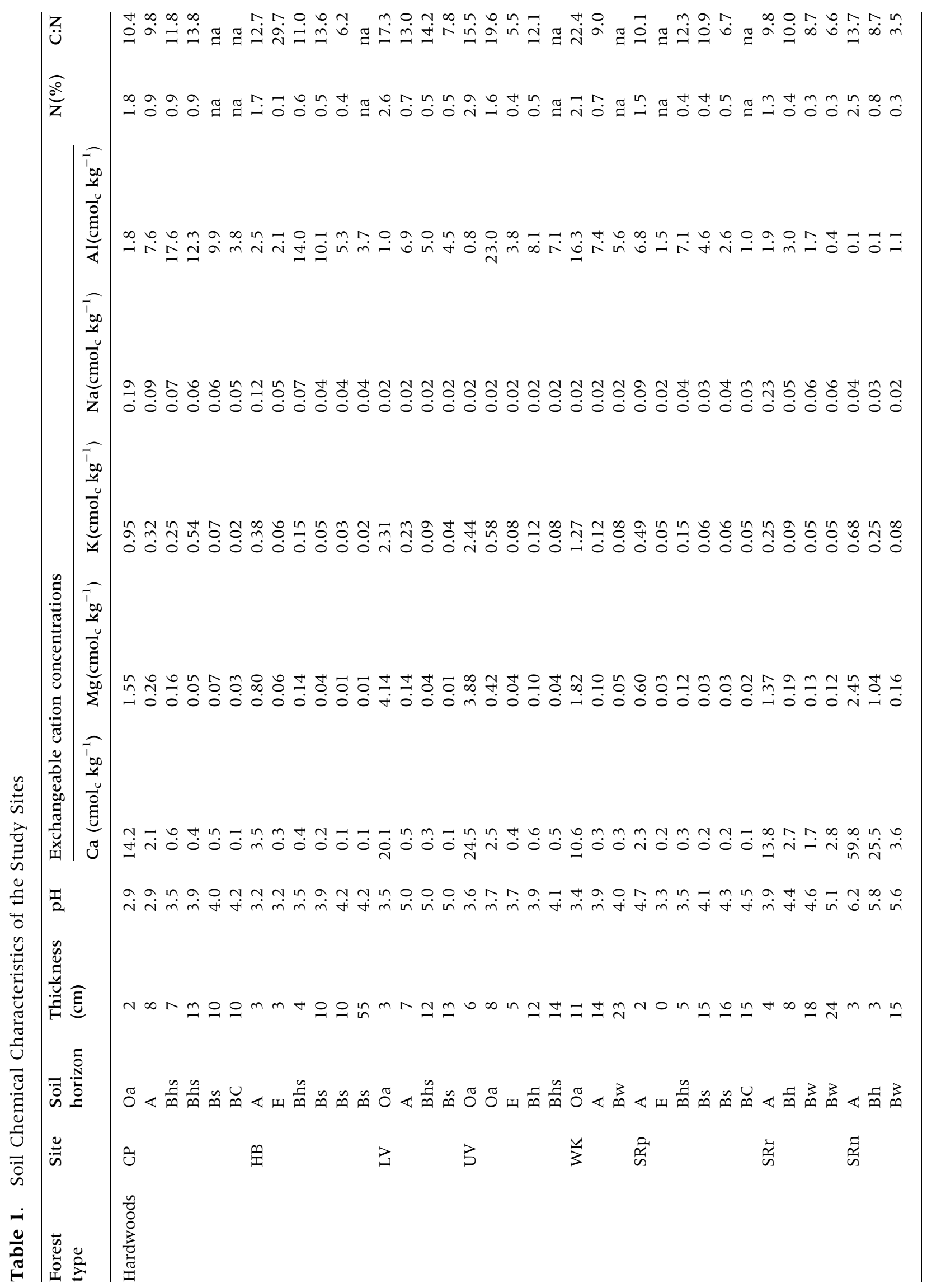




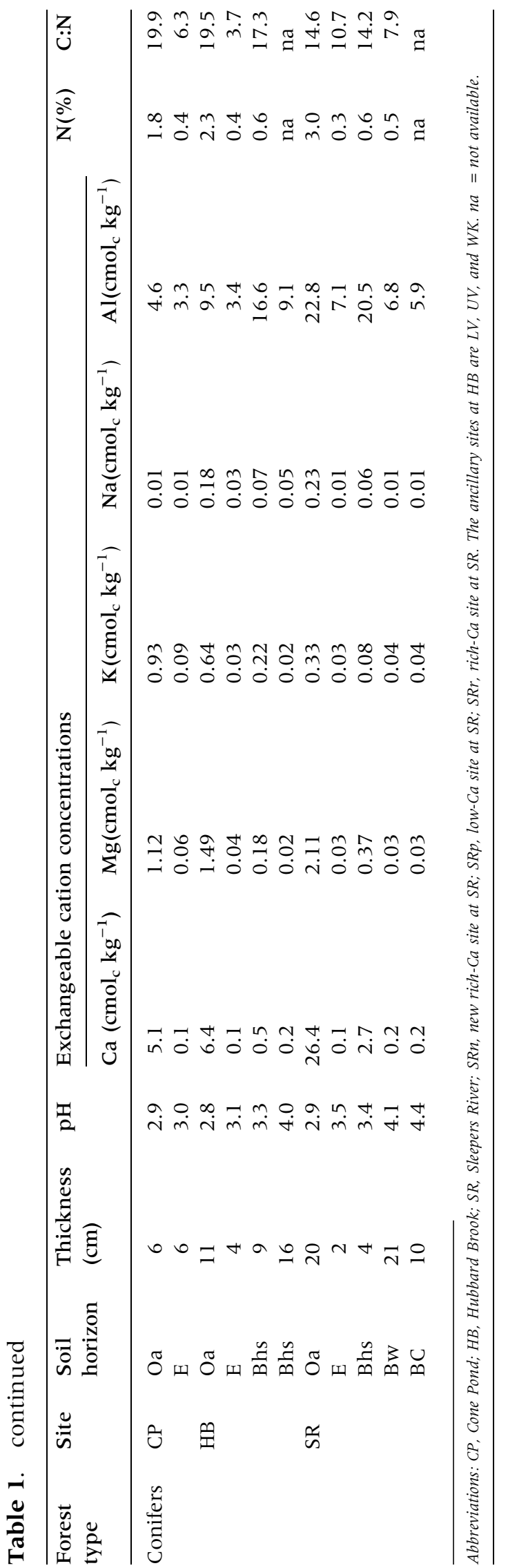

\section{Aboveground Biomass and Production}

Although they had similar basal areas, the hardwood stands had 37\% higher biomass, on average, than the conifer stands (Table 2). Some of this difference reflects differences in canopy height; trees in the hardwood stands averaged 30\% taller than the conifer stands in our study sites. Aboveground biomass was highest at SRn (301 $\mathrm{Mg} \mathrm{ha}^{-1}$ ) and SRr (264 Mg ha-1) (Table 2). Of the conifer stands, CP had greater biomass than the other two sites.

Litterfall mass of hardwoods was $44 \%$ higher than that of conifer stands $(P<0.01)$. Leaf litterfall mass ranged from 2.9-3.3 Mg ha $\mathrm{ha}^{-1}$ for hardwoods and 2.1-2.3 $\mathrm{Mg} \mathrm{ha}^{-1} \mathrm{y}^{-1}$ for conifer stands (Table 2). There were no significant differences in litter production among the five hardwood stands or among the three conifer stands. Leaf production estimated by allometry was $9 \%$ higher than measured leaf litter production, which is consistent with observations of mass loss during senescence (Fahey and others 2005).

Aboveground production was calculated as the sum of litter production and aboveground biomass increment. The average aboveground production of hardwoods was $42 \%$ higher than that of conifer stands. Leaf litter production comprised from 37 to $53 \%$ of aboveground production.

\section{Fine Root Biomass}

We hypothesized that fine root biomass would be greatest in sites with low soil Ca. Across the hardwood stands, however, live root biomass was statistically indistinguishable (Figure 3; $P=0.34$ ). The proportion of live root biomass in very fine $(<0.5 \mathrm{~mm})$ roots was significantly higher in hardwoods $(54 \%)$ than in conifers $(44 \%)(P=0.03)$.

Dead root biomass across the hardwood stands did differ significantly $(P<0.01)$, with one of the rich SR stands (SRn) having only $50 \%$ as much dead root biomass as CP or HB (Figure 3). Conifer fine root biomass was lowest at $\mathrm{HB}(P=0.01$ for live and $P<0.01$ for dead root biomass), which was in the middle of the Ca gradient. Dead roots were a greater fraction of the total root mass in conifers than hardwoods $(P=0.02)$. In conifers, the mass of dead roots was greater than the mass of live roots (average of three stands), whereas in hardwoods, the mass of dead roots was only about half the mass of live roots (average of five stands).

\section{Fine Root Distribution with Depth}

As expected, root biomass declined with depth in all diameter classes in all stands (Figures 4 and 5). 


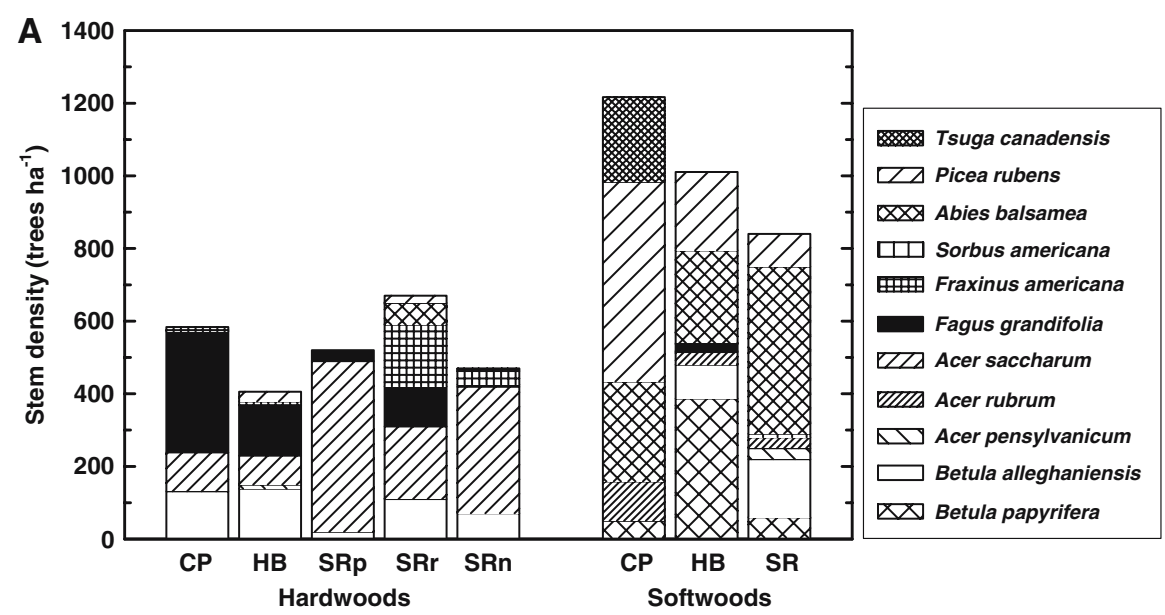

Figure 2. Stem density (A) and basal area (B) of tree species in our eight research sites. See text for site names.

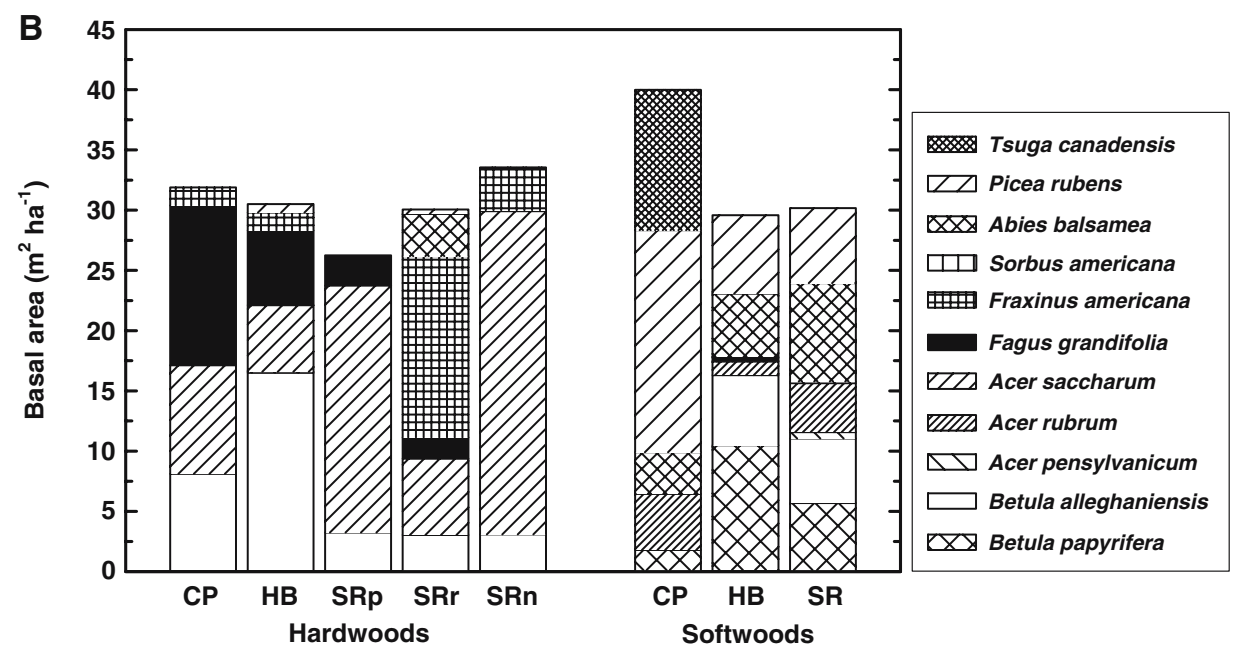

Table 2. Aboveground Production, Biomass, Root Turnover Rate, and Root Production $(<1$ mm roots) at $\mathrm{CP}, \mathrm{HB}$, and SR

\begin{tabular}{|c|c|c|c|c|c|c|c|c|}
\hline \multirow{2}{*}{$\begin{array}{l}\text { Forest } \\
\text { type }\end{array}$} & \multirow[t]{2}{*}{ Site } & \multirow{2}{*}{$\begin{array}{l}\text { Aboveground } \\
\text { biomass } \\
\left(\mathrm{Mg} \mathrm{ha}^{-1}\right)\end{array}$} & \multirow{2}{*}{$\begin{array}{l}\text { Woody } \\
\text { biomass } \\
\text { production } \\
\left(\mathrm{Mg} \mathrm{ha}^{-1} \mathrm{y}^{-1}\right)\end{array}$} & \multirow{2}{*}{$\begin{array}{l}\text { Leaf litter } \\
\text { production } \\
\left(\mathrm{Mg} \mathrm{ha}^{-1} \mathrm{y}^{-1}\right)\end{array}$} & \multirow{2}{*}{$\begin{array}{l}\text { Total } \\
\text { aboveground } \\
\text { production } \\
\left(\mathrm{Mg} \mathrm{ha}^{-1} \mathrm{y}^{-1}\right)\end{array}$} & \multicolumn{2}{|c|}{ Root turnover } & \multirow{2}{*}{$\begin{array}{l}\text { Root } \\
\text { production } \\
\left(\mathrm{Mg} \mathrm{ha}^{-1} \mathrm{y}^{-1}\right)\end{array}$} \\
\hline & & & & & & $\begin{array}{l}\text { Number } \\
\text { of roots }\end{array}$ & $\operatorname{Mean}\left(\mathrm{y}^{-1}\right)$ & \\
\hline \multirow[t]{5}{*}{ Hardwoods } & $\mathrm{CP}$ & 213 & 3.91 & $2.88(1.66)$ & 6.79 & 952 & $1.32(0.18)^{\mathrm{a}}$ & 2.96 \\
\hline & $\mathrm{HB}$ & 214 & 2.94 & $3.25(0.15)$ & 6.19 & 1399 & $0.64(0.06)^{b}$ & 1.19 \\
\hline & SRp & 224 & 3.62 & $3.01(1.74)$ & 6.63 & 2383 & $0.71(0.09)^{\mathrm{b}}$ & 1.46 \\
\hline & $\mathrm{SRr}$ & 264 & 5.47 & $3.34(1.93)$ & 8.81 & 484 & $1.39(0.17)^{\mathrm{a}}$ & 2.11 \\
\hline & SRn & 301 & 4.35 & $3.25(1.63)$ & 7.60 & 303 & $1.86(0.18)^{\mathrm{a}}$ & 3.66 \\
\hline \multirow[t]{3}{*}{ Conifers } & $\mathrm{CP}$ & 197 & 2.22 & $2.11(1.22)$ & 4.33 & 854 & $0.62(0.09)^{b}$ & 0.86 \\
\hline & $\mathrm{HB}$ & 162 & 3.70 & $2.27(0.16)$ & 5.97 & 983 & $1.43(0.22)^{\mathrm{a}}$ & 2.25 \\
\hline & SR & 172 & 3.08 & $2.20(1.27)$ & 5.28 & 895 & $1.52(0.19)^{\mathrm{a}}$ & 2.29 \\
\hline
\end{tabular}

Wood includes heartwood, sapwood, bark, and branch. Production and total aboveground biomass were estimated using the Hubbard Brook Biomass and Productivity program (http://www.hubbardbrook.org/yale/watersheds/w6/biomass-stop/phytow6.htm). Litterfall was measured in this study. Standard errors are in parentheses. Sites sharing the same letter are not significantly different within forest types at $\alpha=0.05$.

For hardwoods, $57 \%$ of the total fine root $(<2 \mathrm{~mm})$ biomass for the profile down to $35 \mathrm{~cm}$ occurred in the forest floor and the top $10 \mathrm{~cm}$ of mineral soil, with $9 \%$ below $25 \mathrm{~cm}$ (Figure 4 ). In conifers, there was an even greater decline in root biomass with depth: $66 \%$ of fine root biomass was above $10 \mathrm{~cm}$ 

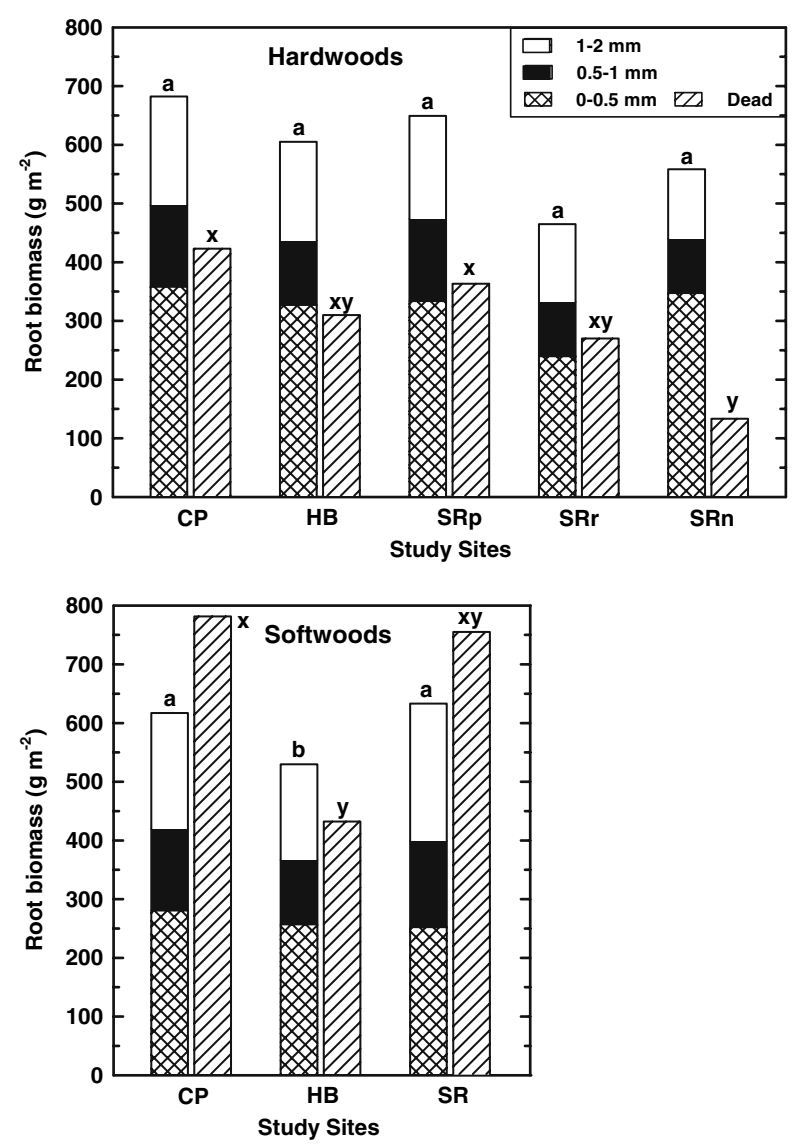

Figure 3. Total fine root biomass of hardwoods and conifers at the study sites in June 2003. Means sharing the same letter within a forest type (hardwoods or conifers) and within a root type (live or dead) are not significantly different among sites.

and $7 \%$ was below $25 \mathrm{~cm}$ (Figure 5). The depth distribution of roots also depended on root diameter, with the finer roots $(<0.5 \mathrm{~mm})$ much more concentrated at shallow depths in both hardwoods and conifers (Figures 4 and 5). There was no significant difference across stands in the depth distribution of live roots, contrary to our hypothesis that the roots would be more concentrated at the surface in the more fertile sites.

Dead roots, unlike live roots, differed by site in their distribution with depth (Figures 4 and 5). In hardwood stands, dead roots declined more steeply with depth in the low-Ca sites (CP, HB, and SRp) than in the high-Ca sites (SRr and SRn) (Figure 4). Similarly, dead roots in conifer stands declined more steeply in the low-Ca site (CP) than the other sites (HB and SR) (Figure 5). The distribution of dead roots with depth differed between hardwoods and conifers, in the opposite direction of the pattern for live roots. The dead roots were more con- centrated near the surface $(<5 \mathrm{~cm}$ depth $)$ in hardwoods $(42 \%$ of total dead roots) than in conifers $(30 \%)(P=0.05)$.

The ratio of dead to live roots in conifers increased markedly with soil depth, but there was no change in this ratio with depth in hardwoods (Figure 6). Dead root biomass was less than live root biomass in all soil strata in hardwoods, but dead root biomass in conifers was larger than live root biomass below $5 \mathrm{~cm}$ soil depth. This difference suggests that root turnover is higher or decomposition of dead roots is slower in deeper soil horizons in the conifer stands.

\section{Fine Root Turnover and Production}

A total of 8250 fine roots were observed through the minirhizotron tubes. Uncorrected fine root turnover coefficients $\left(\mathrm{TC}, \mathrm{y}^{-1}\right)$ varied significantly $(P<0.01)$ across the eight stands, ranging from $0.62 \mathrm{y}^{-1}$ in the conifer stand at CP to $1.86 \mathrm{y}^{1}$ in the hardwood stand at SRn (Table 2). The TC values indicated two distinct groups of stands, three with low root turnover (HB and SRp hardwoods and CP conifers) and five with high root turnover (CP, SRr, and SRn hardwoods and HB and SR conifers). The TC showed a weak negative correlation with fine root biomass measured in the same stands $(r=-0.65 ; \quad P=0.11)$. Although the TC values tended to be higher in surface soil layers, no significant differences in TC were detected across soil depth layers within the sites.

Fine root production was calculated as the product of fine root biomass $(<1 \mathrm{~mm})$ and the mean TC for each site, corrected by a constant factor of 0.45 , as explained in the Methods. Fine root production ranged from 0.86 to $3.67 \mathrm{Mg} \mathrm{ha}^{-1}$ $\mathrm{y}^{-1}$, which was $19-43 \%$ of total aboveground production (Table 2). The range of fine root production was about 3-fold across the hardwood stands, with the lowest values in the low-Ca stands $\left(\mathrm{HB}, \mathrm{SR}_{\mathrm{p}}\right)$ and the highest in the highest-Ca stand $\left(\mathrm{SR}_{\mathrm{n}}\right)$. The lowest fine root production was at the $\mathrm{CP}$ conifer stand, where it was less than half that in the other conifer sites. There were no significant differences in fine root production between hardwoods and conifers $(P=0.52)$.

\section{Productivity and Biomass Allocation Along the Ca Gradient}

We used the exchangeable $\mathrm{Ca}$ of the surface soil horizon (Table 1) as one index of soil Ca status, based on the observation that fine roots were most concentrated there (Figures 4 and 5). There was 

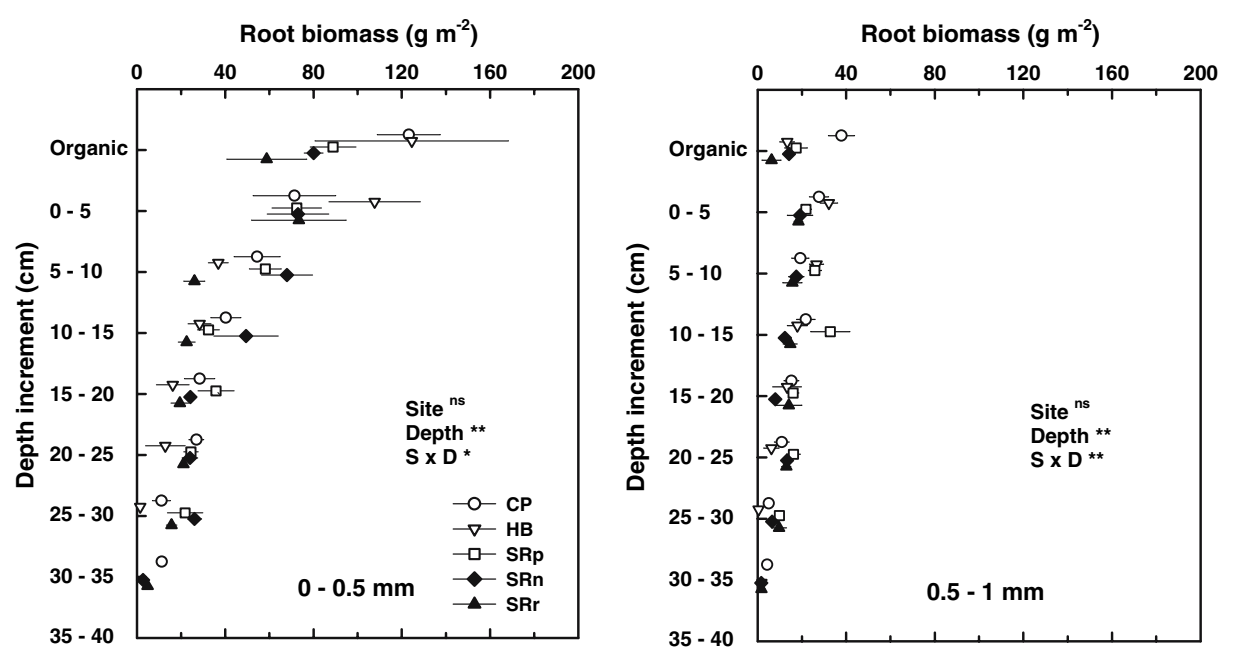

Figure 4. Fine root biomass distribution (mean $\pm \mathrm{SE}$, $n=5$ ) of hardwoods with soil depth in sites of differing $\mathrm{Ca}$ availability. Repeatedmeasures ANOVA identified the effect of site (S), depth (D), and the interaction of site with depth $(\mathrm{S} \times \mathrm{D})$. * $P<0.05 ; * * P<0.01$; ns, not significant.
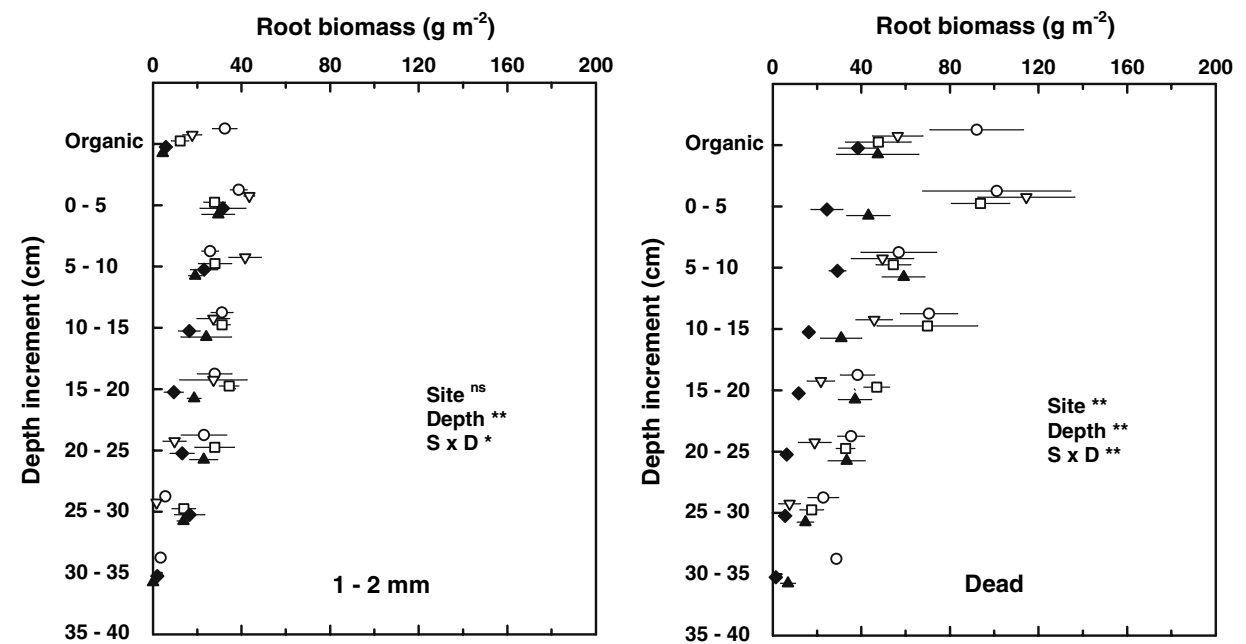

no relationship of aboveground productivity to the Ca gradient, so defined $(P=0.43)$. However, both fine root production and TC were significantly correlated with soil exchangeable $\mathrm{Ca}$ (Figures 7 and 8). When we added three ancillary hardwood stands from HB to the data set for TC and soil Ca, a highly significant correlation also was observed across eight hardwood stands $(r=0.79 ; P=0.02)$; hence, it appears that within the hardwood forest type, TC increases with increasing soil exchangeable Ca.

The highest correlation with root turnover across our eight stands was for exchangeable Ca of the uppermost horizon $(r=0.65 ; P=0.03)$. The Ca:Al ratio in this horizon showed a somewhat weaker correlation with root turnover $(r=0.60 ; P=0.05)$. Other soil chemistry parameters including exchangeable $\mathrm{Al}, \mathrm{pH}$, organic matter content, $\mathrm{N}$ content and C:N ratio were not correlated with root turnover $(r \leq 0.39 ; P \geq 0.23)$. Similarly, site variables such as elevation, aspect, slope, and depth to redoximorphic features (that is, drainage) were not related to root turnover $(r \leq 0.35 ; P \geq 0.28)$.

Expressing soil chemistry parameters as a single value for the whole profile, weighted by the root density in each genetic horizon, gave similar results. Root turnover was most highly correlated with the Ca:Al ratio $(r=0.63 ; P=0.04)$, and somewhat less correlated with the exchangeable $\mathrm{Ca}$ $(r=0.59 ; P=0.06)$ on a whole-profile basis. The other soil chemistry parameters, again, were not correlated with root turnover.

Fine root production showed similar relationships to soil and site parameters. Exchangeable Ca of the uppermost horizon had the highest correlation $(r=0.78 ; P=0.02)$, whereas Ca:Al ratio had a marginally significant correlation with fine root production $(r=0.69 ; P=0.06)$. Other soil and site parameters were not correlated with fine root production.

The ratio of fine root biomass to leaf litter production was not significantly related to exchange- 

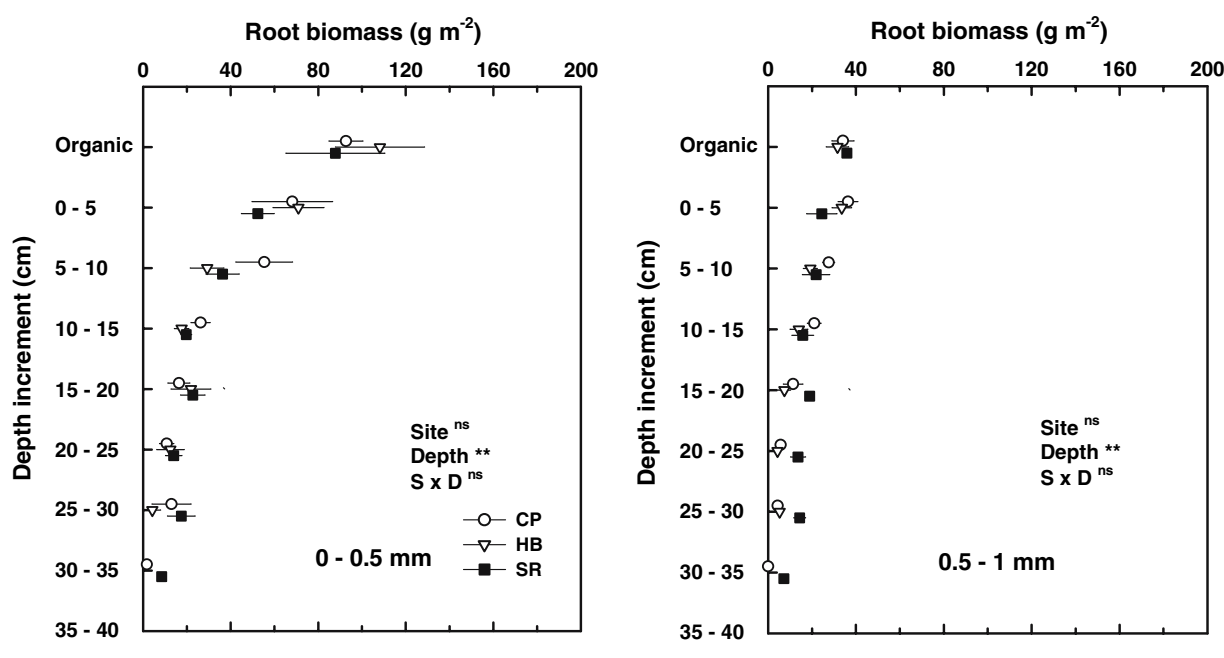

Figure 5. Fine root biomass distribution (mean $\pm \mathrm{SE}$, $n=5$ ) of conifers with soil depth in sites of differing $\mathrm{Ca}$ availability. Repeatedmeasures ANOVA identified the effect of site (S), depth (D), and the interaction of site with depth $(\mathrm{S} \times \mathrm{D})$. * $P<0.05 ; * * P<0.01$; ns, not significant. Cores at SR were divided into $5-\mathrm{cm}$ increments because the entire $35 \mathrm{~cm}$ was organic.
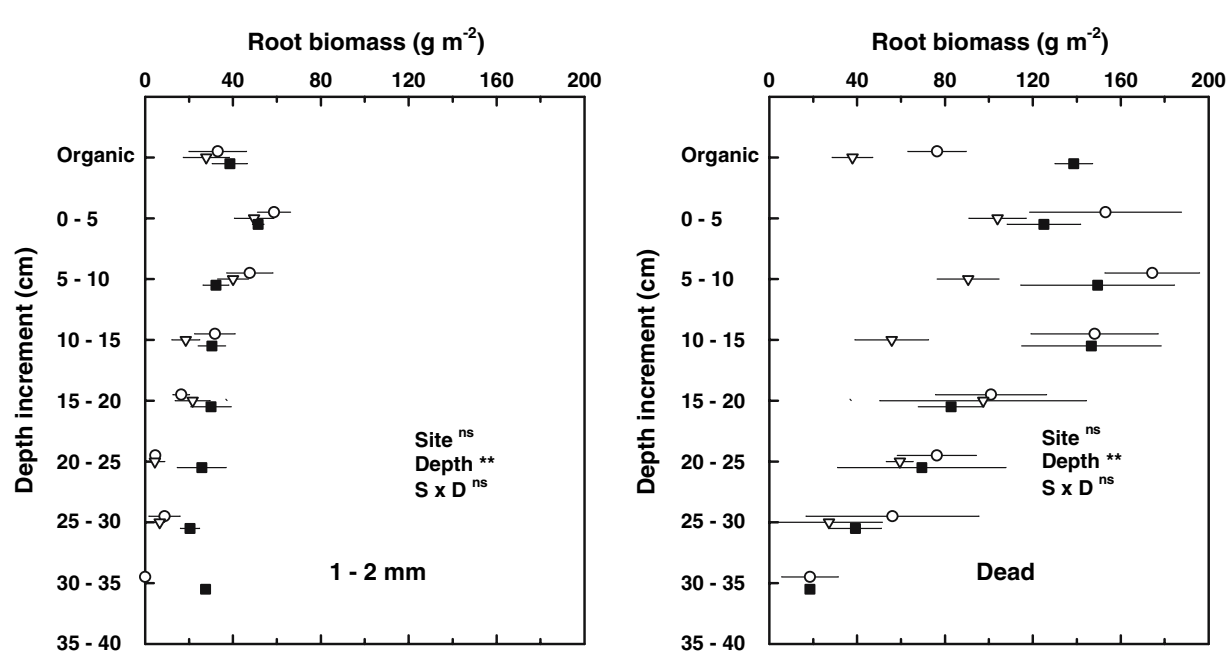

able Ca. However, the ratio of fine root production to the sum of root and leaf litter production was positively related to exchangeable $\mathrm{Ca}(P=0.10)$ (Figure 9). In other words, a greater fraction of carbon was allocated to root production compared to leaf production as soil exchangeable $\mathrm{Ca}$ increased.

\section{Discussion}

Our study of forest production in eight stands indicated that neither aboveground biomass and production nor belowground biomass were significantly related to soil Ca availability. However, our study is the first to demonstrate a pattern of increasing belowground carbon allocation with increasing soil $\mathrm{Ca}$ status in forest ecosystems. This pattern resulted from significantly higher fine root turnover (shorter root longevity) in high-Ca soils both for hardwood stands and for all stands combined, including three conifer stands. These results extend our limited understanding of the effects of nutrient availability on belowground carbon allocation (Gower and others 1992; Nadelhoffer and Raich 1992; Burton and others 2000; King and others 2002) and suggest that differences in soil parent material can strongly influence fine root dynamics. Moreover, continuing depletion of soil bases resulting from anthropogenic activity could alter the future $\mathrm{C}$ dynamics in forests by this mechanism.

\section{Fine Root Biomass}

Contrary to expectations based on studies of nitrogen or phosphorus gradients, fine root biomass $(<2 \mathrm{~mm})$ did not vary consistently with Ca availability. Theoretically, in sites with favorable nutrient and water availability, trees should allocate carbon preferentially to canopy growth and maintenance, and less to fine root biomass. This relationship has been observed in sites varying in $\mathrm{N}$ availability (Nadelhoffer and others 1985) or site index (Keyes and Grier 1981; Vanninen and Makela 1999). 


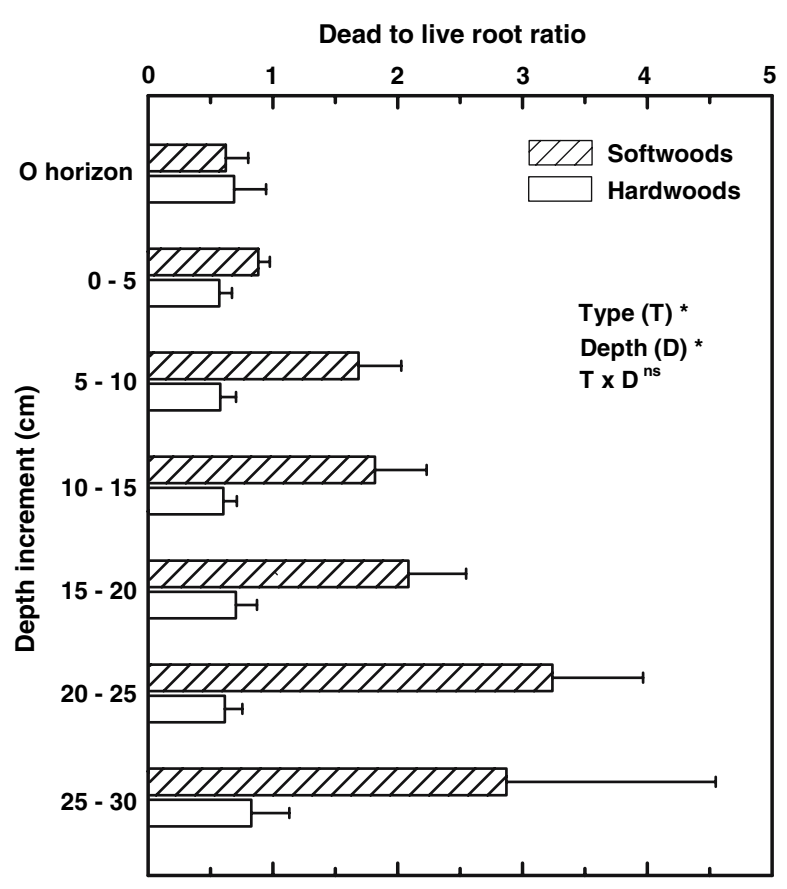

Figure 6. Dead to live root ratio with soil depth in hardwoods and conifers. Repeated-measures ANOVA identified the significance of forest type (T), depth (D), and the interaction of type with depth $(\mathrm{T} \times \mathrm{D})$ : $*=P<0.05 ; \mathrm{ns}=$ not significant.

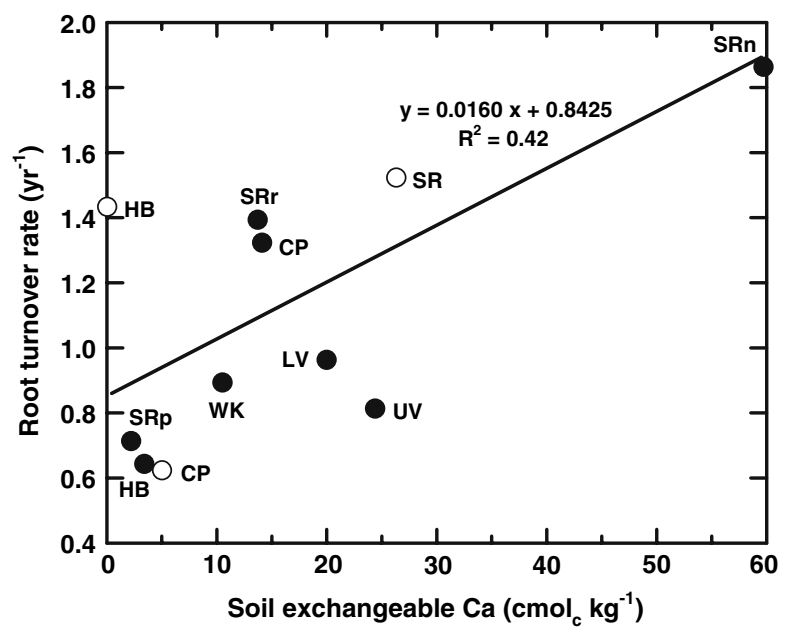

Figure 7. Fine root turnover in hardwoods and conifers along a Ca gradient defined by soil exchangeable $\mathrm{Ca}$ in the $\mathrm{O}$ or $\mathrm{A}$ horizon, including three ancillary hardwood stands at the HB site.

There are several possible reasons why differences in fine root biomass were not found across the Ca gradient in our study. First, fine roots may not respond to Ca availability in the same way as to $\mathrm{N}$ availability. Although $\mathrm{Ca}$ availability affects the growth and health of some tree species, such as

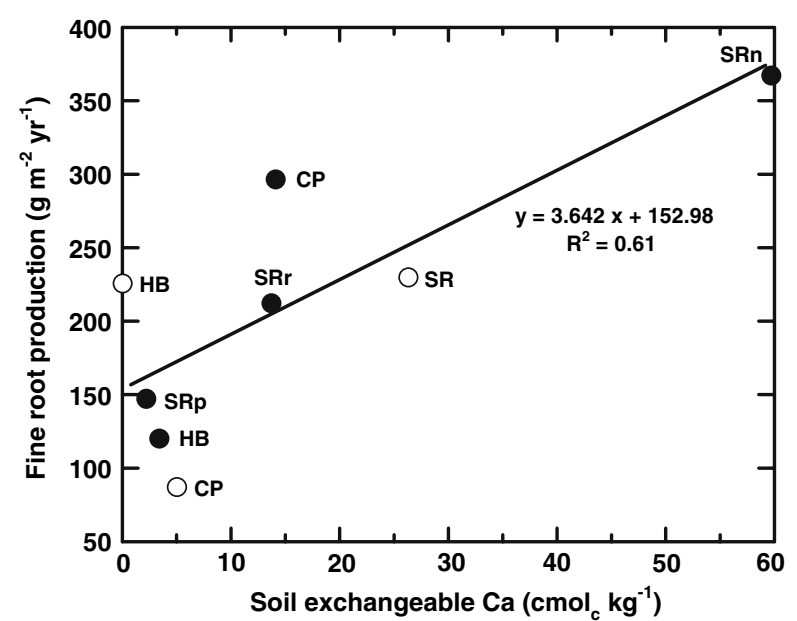

Figure 8. Fine root production in hardwoods and conifers along a soil Ca gradient (exchangeable $\mathrm{Ca}$ in the $\mathrm{O}$ or A horizon) at the eight study sites.

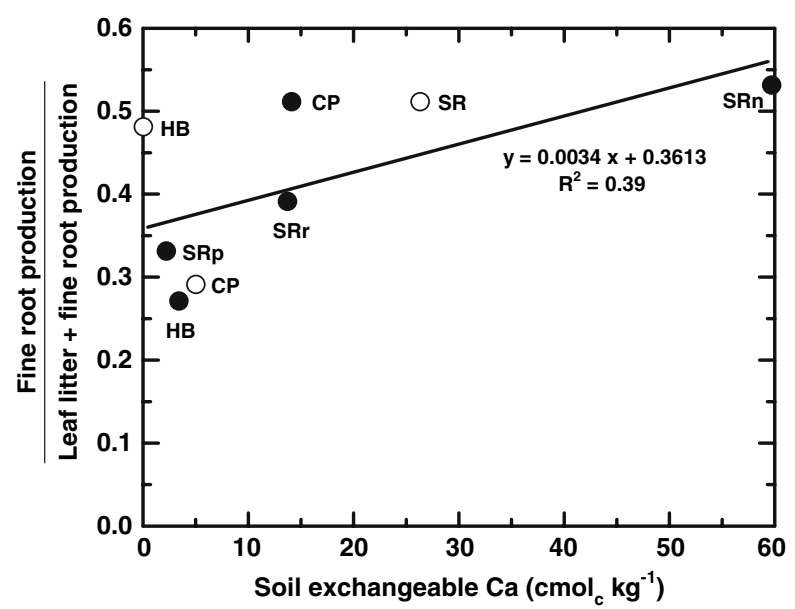

Figure 9. Fine root production as a fraction of root and leaf litter production along a Ca gradient defined by soil exchangeable $\mathrm{Ca}$ in the $\mathrm{O}$ or $\mathrm{A}$ horizon.

sugar maple (Wilmot and others 1995; Long and others 1997) and red spruce (DeHayes and others 1999), it is not generally thought to limit growth of natural vegetation. Second, the large spatial variation in fine root biomass within stands limits the power to detect differences among stands. In both forest types, the coefficient of variation (CV) within stand $(21 \%$ for conifers and $27 \%$ for hardwoods) was twice as large as the CV among stands (4\% for conifers and $14 \%$ for hardwoods). Given the variation within sites, a difference of $2.3 \mathrm{Mg} \mathrm{ha}^{-1}(40 \%$ of the average of 5 hardwood stands) for fine roots of hardwoods and $1.4 \mathrm{Mg} \mathrm{ha}^{-1}$ (25\% of the average of three stands) for conifers would have been 
required to constitute a significant difference at $\alpha=0.05$.

Third, although the stands were chosen to maximize variation in soils while holding other variables constant, it was impossible to avoid some variation in forest composition. Hence, differences in composition among the hardwood stands, most notably the differing abundances of beech and white ash (Figure 2), could have affected fine root biomass patterns. Similarly, in the conifers, the differing contribution of hemlock and birches across the stands (Figure 2) may have complicated any patterns related to soil Ca availability.

We measured fine root biomass at $\mathrm{HB}$ to be $26 \%$ more than the value $\left(4.7 \mathrm{Mg} \mathrm{ha}^{-1}\right)$ reported from the same hardwood stand by Fahey and Hughes (1994). Our values are only 7\% higher for 0-1 mm roots, but $150 \%$ higher for $1-2 \mathrm{~mm}$ roots. This discrepancy in the larger size class of fine roots may be due to differences in soil core diameter $(5 \mathrm{~cm}$ in this study and $2 \mathrm{~cm}$ in Fahey and Hughes 1994); the smaller cores appear to be less effective in sampling small woody roots. For example, at the nearby Bartlett Experimental Forest, smaller core sizes resulted in higher variation and less accuracy in fine root sampling especially at higher root diameters (Park and others 2006).

\section{Fine Root Distribution with Depth}

We observed no differences in fine root depth distribution with Ca availability. It seems that physical and biological factors had more influence on fine root distribution. By improving soil physical conditions, earthworms at SRr might be responsible for the significantly higher fine root biomass at $0-5 \mathrm{~cm}$ depth. This effect occurred only in roots smaller than $0.5 \mathrm{~mm}$, which was consistent with the result of Fisk and others (2004) that roots larger than $1 \mathrm{~mm}$ in diameter were not influenced by the presence of earthworms. In hardwood stands at HB, fine root biomass declined abruptly below $5 \mathrm{~cm}$ depth. The E horizon develops at about $5 \mathrm{~cm}$ soil depth; this horizon has low root biomass because of its exceedingly low nutrient availability (Eissenstat and Yanai 1997).

Root depth distributions differed between hardwood and conifer stands. Because conifers, being shallow-rooted, are better adapted to sites where resources are concentrated near the soil surface, the steep decrease of finer roots $(<0.5 \mathrm{~mm})$ in conifers was not surprising. For example, sugar maple allocates more to fine roots in deep soil than hemlock (Dijkstra and Smits 2002) and has a greater potential to absorb mineral nutrients in deep soil (Finzi and others 1998). Because species type may influence vertical root distribution (Gale and Grigal 1987), the variation in species composition within hardwood and conifer types may have limited our ability to detect differences in root distribution with soil depth.

\section{Fine Root Production}

Our estimates of fine root production in hardwood stands are similar to those of Burke and Raynal (1994), Fahey and Hughes (1994), and Joslin and Henderson (1987). Although fine root biomass did not vary systematically across the gradient, fine root production increased significantly with increasing soil Ca availability. This pattern is analogous with reports for northern hardwood forests in relation to $\mathrm{N}$ availability (Nadelhoffer and others 1985; Kubiske and others 1998; Burton and others 2000; Pregitzer and others 2000), but contrasts with those of western coniferous forests in North America (Grier and others 1981; Vogt and others 1986; Gower and others 1992), in which fine root production was greater at sites with low nutrient availability.

As in other studies (McClaugherty and Others 1982), we found no significant differences in fine root production between hardwood and conifer stands, because the variability within forest types was much greater than between forest types. Surprisingly, however, we found that the ratio of dead to live roots was significantly greater in conifer than hardwood stands and this ratio increased markedly with soil depth in the conifer stands. This pattern could be due to differences between hardwoods and conifers in the decomposition rate of dead roots (Silver and Miya 2001), or it might be the result of a transient effect of recent mortality, though no clear cause of such mortality was apparent. In Norway spruce (Picea abies L.) in Sweden, the ratio of dead to live fine roots gradually increased with depth (Persson and Ahlström 2002). Because we detected no significant differences by soil depth in root turnover in hardwoods, it seems more likely that root decomposition differs with soil depth between forest types. Further mechanistic study of this pattern is warranted.

Most of the pattern in fine root production across the Ca gradient was associated with differences in the root turnover coefficient (TC) measured with minirhizotrons; TC appeared to increase with soil Ca availability in both hardwood and conifer stands, but the number of stands of each type was small. The availability of TC data, collected with the same methodology and over the same time period, 
for three ancillary hardwood stands at HB, provided more points for the comparison of TC with soil exchangeable $\mathrm{Ca}$ in northern hardwood forests (Figure 7). This relationship, coupled with significantly lower root tissue Ca concentrations in the Ca-poor sites (Park 2006), suggests that annual Ca recycling in low-Ca soils is much lower than in high-Ca soils and likely acts as a positive feedback to greater Ca stress of trees in nutrient-poor sites.

The mechanisms contributing to the higher root turnover in the sites with higher Ca deserve further detailed study. Root turnover increases with tissue $\mathrm{N}$ concentration, possibly because of higher metabolic rates of high $\mathrm{N}$ roots (Burton and others 2000); however, $\mathrm{N}$ concentrations in fine roots did not differ significantly across the Ca availability gradient (Park 2006). Presumably, other factors associated with soil $\mathrm{pH}$ and base saturation influence fine root turnover. For example, nitrification potential generally increases with soil $\mathrm{pH}$ (DeBoer and Kowalchuk 2001) and root turnover may be higher in nitrate-rich soils (Aber and others 1985); alternatively, soil fauna that consume roots could be more abundant at higher $\mathrm{pH}$. In any case, the higher fine root production in the high-Ca sites is sufficient to maintain similar amounts of fine root biomass despite higher turnover rates (Figure 3, Table 2).

We acknowledge some uncertainties associated with our estimates of TC using the minirhizotron method. In particular, because we used a root number rather than a root length approach to calculate TC, major differences in root system branching and morphology among the stands could affect the comparisons across the Ca gradient. Unfortunately, the very high labor costs of tracing thousands of individual roots precluded root length determinations in this study. Tierney and Fahey (2001) demonstrated that TC estimates were only moderately sensitive to whether root number, length or biomass were measured in the minirhizotron method, which makes it unlikely that differences in root system morphology would be large enough to significantly affect our comparisons. Moreover, our estimate of fine root turnover at HB was very similar to an earlier independent estimate using minirhizotrons in the same forest stand (Tierney and Fahey 2001). Nevertheless, our conclusion that fine root turnover increases with soil Ca availability should be regarded as somewhat tentative. It is notable that this relationship holds within the four hardwood stands at $\mathrm{HB}$ and also within the three stands at SR; the pattern is less impressive within the conifer stands (Figure 7).

\section{Carbon Allocation}

Our results showed a higher proportion of carbon allocation to roots than leaves in sites with higher Ca status; leaf litter was not significantly related to the soil Ca gradient by forest types $(P=0.61$ for hardwoods and $P=0.82$ for conifers) or by whole sites $(P=0.79)$. In contrast, both leaf litter production and fine root production have been reported to be high in sites with high $\mathrm{N}$ availability (Nadelhoffer and others 1983; Nadelhoffer and Raich 1992). There are no other studies that have measured or estimated leaf litter production simultaneously with fine root production along a Ca gradient.

Although fine root biomass comprised only 1.5$3.0 \%$ of total forest biomass in all stands, the contribution of fine root production was approximately $17 \%$ of the sum of root and aboveground production in the low-Ca sites and 30\% in the high-Ca sites. Recent summaries of root production in temperate forests indicate that it comprises an average of about $25 \%$ in both deciduous and evergreen stands (Lauenroth and Gill 2003; Tierney and Fahey 2007).

The effect of soil nutrient availability on belowground production should be considered for inclusion in models of carbon sequestration in forest ecosystems. The effect of acid deposition, according to our results, might be to reduce belowground carbon allocation and nutrient inputs in forest ecosystems as soil Ca availability declines. Although this effect might allow sustained high aboveground production, the positive feedback to reduced Ca availability could push the soil past a threshold where forest health deteriorates and forest decline ensues (DeHayes and others 1999). On the other hand, the accompanying $\mathrm{N}$ deposition to soils would be predicted to oppose this effect on root turnover rates. Multi-dimensional gradients would be required to distinguish the effects of individual nutrients.

\section{ACKNOWLEDGMENTS}

We thank Amber Knowlden, Joo Sung Kim, Byung Kwon Park, Asuka Matsuzaki, and Mutsumi Nishii for many hours of sorting roots. This project was funded by the Northeastern States Research Cooperative, the National Science Foundation (DEB 0235650), the NSF Long-Term Ecological Research program (0423259), and the Korea Forest Service (S210606L0101104). This article is a contribution to the Hubbard Brook Ecosystem Study. 


\section{REFERENCES}

Aber JD, Melillo JM, Nadelhoffer KJ, McClaugherty CA, Pastor J. 1985. Fine root turnover in forest ecosystems in relation to quantity and form of nitrogen availability: a comparison of two methods. Oecologia 66:317-21.

Arthur MA, Siccama TG, Yanai RD. 1999. Calcium and magnesium in wood of northern hardwood forest species: relations to site characteristics. Can J For Res 29:339-46.

Bailey SW, Horsley SB, Long RP, Hallett RA. 2004. Influence of edaphic factors on sugar maple nutrition and health on the Allegheny plateau. Soil Sci Soc Am J 68:243-52.

Black KE, Harbron CG, Franklin M, Atkinson D, Hooker JE. 1998. Differences in root longevity of some tree species. Tree Physiol 18:259-64.

Blume LJ, Schumacher BA, Schaffer PW, Cappo KA, Papp ML, van Remortel RD, Coffey DS, Johnson MG, Chaloud DJ. 1990. Handbook or methods for acid deposition studies laboratory analyses for soil chemistry. EPA/600/4-90/023. Las Vegas, NY: USEPA, Environmental Monitoring Systems Laboratory.

Bormann FH, Likens GE.. 1994. Pattern and process in a forested ecosystem: disturbance, development, and the steady state based on the Hubbard Brook Ecosystem Study. New York, USA: Springer-Verlag.

Burke MK, Raynal DJ. 1994. Fine root growth phenology, production, and turnover in a northern hardwood forest ecosystem. Plant Soil 162:135-46.

Burton AJ, Pregiter KS, Hendrick RL. 2000. Relationships between fine root dynamics and nitrogen availability in Michigan northern hardwood forests. Oecologia 125:389-99.

Buso DC, Martin CW, Hornbeck JW. 1984. Potential for acidification of six remote ponds in the White Mountains of New Hampshire. New Hampshire Water Resources Research Center, Durham, Research Report 62, Durham, NH, 57 pp.

Cleavitt NL, Fahey TJ, Groffman PM, Hardy JP, Henry KS, Driscoll CT. 2008. Effects of soil freezing on fine roots in a northern hardwood forest. Can J For Res 38:82-91.

Coleman MD, Dickson FE, Isebrands JG. 2000. Contrasting fineroot production, survival and soil $\mathrm{CO}_{2}$ efflux in pine and poplar plantations. Plant Soil 225:129-39.

Cronan CS, Grigal DF. 1995. Use of calcium/aluminum ratios as indicators of stress in forest ecosystems. J Environ Qual 24:209-26.

Darrall NM. 1989. The effect of air pollutants on physiological processes in plants. Plant Cell Environ 12:1-30.

DeBoer W, Kowalchuk GA. 2001. Nitrification in acid soils: micro-organisms and mechanisms. Soil Biol Biochem 33:853-66.

DeHayes DH, Schaberg PG, Hawley GJ, Strimbeck GR. 1999. Acid rain impacts on calcium nutrition and forest health. BioScience 49:789-800.

Dijkstra FA, Smits MM. 2002. Tree species effects on calcium cycling: the role of calcium uptake in deep soils. Ecosystems 5:385-98

Eissenstat DM, Yanai RD. 1997. The ecology of root lifespan. Adv Ecol Res 27:1-60.

Fahey TJ, Hughes JW. 1994. Fine root dynamics in a northern hardwood forest ecosystem, Hubbard Brook Experimental Forest, NH. Ecology 82:533-48.

Fahey TJ, Siccama TC, Driscoll CT, Likens GE, Campbell J, Johnson CE, Aber JD, Cole JJ, Fisk MC, Groffman PM, Hamburg SP, Holmes RT, Schwarz PA, Yanai RD. 2005. The biogeochemistry of carbon at Hubbard Brook. Biogeochemistry 75:109-76.

Federer AC, Hornbeck JW, Tritton LM, Martin WC, Pierce RS, Smith TC. 1989. Long-term depletion of calcium and other nutrients in eastern US forests. Environ Manage 13:593-601.

Finzi AC, Canham CD, Breemen NV. 1998. Canopy tree-soil interactions within temperate forests: species effects on $\mathrm{pH}$ and cations. Ecol Appl 8:447-54.

Fisk MC, Fahey TJ, Groffman PM, Bohlen PJ. 2004. Earthworm invasion, fine-root distributions, and soil respiration in North temperate forests. Ecosystems 7:55-62.

Gale MR, Grigal DF. 1987. Vertical root distributions of northern tree species in relation to successional status. Can J For Res 17:829-34.

Gill RA, Jackson BB. 2000. Global patterns of root turnover for terrestrial ecosystems. New Phytol 147:13-31.

Gower ST, Pongracic S, Landsberg JJ. 1996. A global trend in belowground carbon allocation: can we use the relationship at smaller scales?. Ecology 77:1750-5.

Gower ST, Vogt KA, Grier CC. 1992. Carbon dynamics of rocky mountain Douglas-fir: influence of water and nutrient availability. Ecological Monogr 61:43-65.

Grier CC, Vogt KA, Keyes MR, Edmonds RL. 1981. Biomass distribution and above- and below-ground production in young and mature Abies amabilis zone ecosystems of the Washington Cascades. Can J For Res 11:155-67.

Hendrick RL, Pregitzer KS. 1992. The demography of fine roots in a northern hardwood forest. Ecology 73:1094-104.

Hornbeck JW, Bailey SW, Buso DC, Shanley JB. 1997. Streamwater chemistry and nutrient budgets for forested watersheds in New England: variability and management implications. For Ecol Manage 93:73-89.

Ingestad T, Agren GI. 1995. Plant nutrition and growth: basic principles. Plant Soil 168-9:15-20.

Joslin JD, Henderson GS. 1987. Organic matter and nutrients associated with fine root turnover in a white oak stand. Forest Sci 33:330-46.

Joslin JD, Wolfe MH. 1999. Disturbances during minirhizotron installation can affect root observation data. Soil Sci Soc Am J 63:218-21.

Keyes MR, Grier CC. 1981. Above-and below-ground net production in 40-year-old Douglas-fir stands on low and high productivity sites. Can J For Res 11:599-605.

King JS, Albaugh TJ, Allen HL, Buford M, Strain BR, Dougherty P. 2002. Below-ground carbon input to soil is controlled by nutrient availability and fine root dynamics in loblolly pine. New Phytol 154:389-98.

Knapp AK, Smith MD. 2001. Variation among biomes in temporal dynamics of aboveground primary production. Science 291:481-4.

Kubiske ME, Pregitzer KS, Zak DR, Mikan CJ. 1998. Growth and $\mathrm{C}$ allocation of Populus tremuloides genotypes in response to atmospheric $\mathrm{CO} 2$ and soil $\mathrm{N}$ availability. New Phytol 140:251-60.

Lauenroth WK, Gill R. 2003. Turnover of root systems. In: deKroon H, Visser EJW, Eds. Root ecology. New York: Springer. pp 61-90.

Likens GE, Driscoll CT, Buso DC. 1996. Long-term effects of acid rain: response and recovery of a forest ecosystem. Science 272:244-6. 
Long RP, Horsley SB, Lilja PR. 1997. Impact of forest liming on growth and crown vigor of sugar maple and associated hardwoods. Can J For Res 27:1560-73.

McClaugherty CA, Aber JA, Melillo JM. 1982. The role of fine roots in the organic matter and nitrogen budgets of two forested ecosystems. Ecology 63:1481-90.

McLaughlin SB, Tjoelker MG, Roy WK. 1993. Acid deposition alters red spruce physiology: laboratory studies support field observations. Can J For Res 23:380-6.

Nadelhoffer KJ, Aber JD, Melillo JM. 1983. Leaf-litter production and soil organic matter dynamics along a nitrogenavailability gradient in Southern Wisconsin (U.S.A.). Can J For Res 13:12-21.

Nadelhoffer KJ, Aber JD, Melillo JM. 1985. Fine roots, net primary production, and soil nitrogen availability: a new hypothesis. Ecology 66:1377-90.

Nadelhoffer KJ, Raich JW. 1992. Fine root production estimates and belowground carbon allocation in forest ecosystems. Ecology 73:1139-47.

Park BB. 2006. Fine root dynamics and tissue chemistry across a calcium gradient in temperate hardwood and softwood forest ecosystems, NY. Ph. D. dissertation, College of Environmental Science and Forestry, Syracuse, New York..

Park BB, Yanai RD, Vadeboncoeur MA, Hamburg SP. 2006. Estimating root biomass in rocky soils using pits, cores, and allometric equations. Soil Sci Soc Am J 71:206-13.

Persson H, Ahlstrom K. 2002. Fine-root response to nitrogen supply in nitrogen manipulated Norway spruce catchment areas. For Ecol Manage 168:29-41.

Pregitzer KS, King JS, Burton AJ, Brown SE. 2000. Responses of tree fine roots to temperature. New Phytol 147:105-15.

Raich JW, Nadelhoffer KJ. 1989. Belowground carbon allocation in forest ecosystems: global trends. Ecology 70:1346-54.

Robarge WP, Fernandez I. 1987. Quality assurance methods manual for laboratory analytical techniques. Corvallis, OR: USEPA.

Schwarz PA, Fahey TJ, McCulloch CM. 2003. Factors controlling spatial variation of tree species abundance in a forested landscape. Ecology 84:1862-78.

Shanley JB, Sundquist ET, Kendall C. 1995. Water, energy, and biogeochemical budget research at Sleepers River Research Watershed, Vermont. US geological survey open-file report, 94-475, p 22.

Shortle WC, Smith KT. 1988. Aluminum-induced calcium deficiency syndrome in declining red spruce. Science 240:1017-8.
Siccama TG, Hamburg SP, Arthur MA, Yanai RD, Bormann FH, Likens GE. 1994. Corrections to allometric equations and plant tissue chemistry for Hubbard Brook Experimental Forest. Ecology 75:246-8.

Silver WL, Miya RK. 2001. Global patterns in root decomposition: comparisons of climate and litter quality effects. Oecologia 129:407-19.

Soil Survey Division Staff. 1993. Soil survey manual. Soil Conservation Service. U.S. Department of Agriculture Handbook 18.

Taylor HM. 1987. Minirhizotron observation tubes: methods and applications for measuring rhizosphere dynamics. Madison, WI, USA: Amer. Soc. Agron. Spec. Publ. No. 50.

Thorne JF, Anderson JE, Horiuchi KM. 1988. Cation cycling in a base-poor and base-rich northern hardwood forest ecosystem. J Environ Qual 17:95-101.

Tierney GL, Fahey TJ. 2001. Evaluating minirhizotron estimates of fine root dynamics in a northern hardwood forest. Plant Soil 229:167-76.

Tierney GL, Fahey TJ. 2002. Fine root turnover in a northern hardwood forest: a direct comparison of the radiocarbon and minirhizotron methods. Can J For Res 32:1692-7.

Tierney GL, Fahey TJ. 2007. Estimating belowground primary productivity. In: Knapp AK, Fahey TJ, Eds. Principles and standards for measuring net primary production in long-term ecological studies. Oxford, New York: Oxford University Press. pp 120-41.

Vanninen P, Makela A. 1999. Fine root biomass of Scots pine stands differing in age and soil fertility in Southern Finland. Tree Physiol 19:823-30.

Vogt KA, Grier CC, Vogt DJ. 1986. Production, turnover, and nutrient dynamics of above- and belowground detritus of world forests. Adv Ecol Res 15:303-77.

Vogt KA, Vogt DJ, Palmiotto PA, Boon P, O'Hara J, Asbjornsen H. 1996. Review of root dynamics in forest ecosystems grouped by climate, climatic forest type and species. Plant Soil 187:159-219.

Whittaker RH, Bormann FH, Likens GE, Siccama TG. 1974. The Hubbard Brook ecosystem study: forest biomass and production. Ecol Monogr 44:233-52.

Wilmot TR, Ellsworth DS, Tyree MT. 1995. Relationships among crown condition, and stand nutrition in seven northern Vermont sugarbushes. Can J For Res 25:386-97. 